DOI : 10.31357/fhssphd.2002.00712

The work described in this thesis was carried out by me as an academic candidate of the University of Sri Jayewardenepura under special privileges and a report on this has not been submitted in whole or in part to any University for another Degree/Diploma.

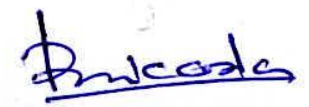

Signature of the candidate
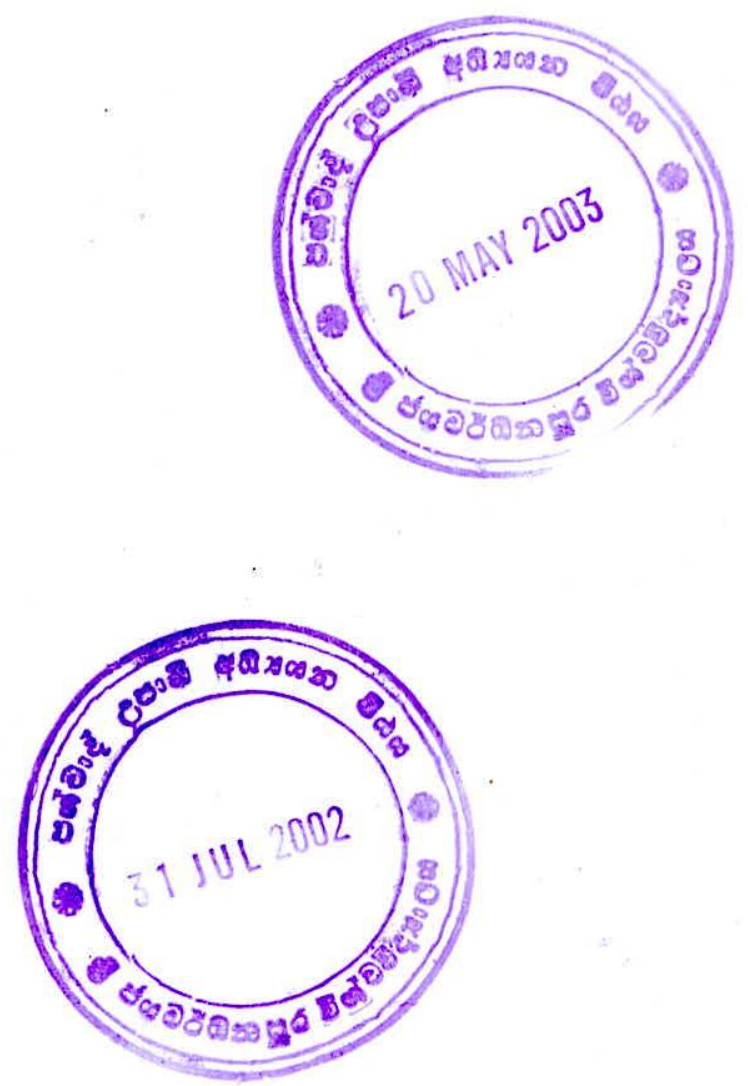


\title{
THE IMPACT OF POLITICS ON SOCIAL WELFARE POLICIES A STUDY OF POST-INDEPENDENCE SRI LNKA 1948-2000
}

\author{
By \\ Piyadasa Athukoralage
}

Thesis submitted to the University of Sri Jayewardenepura for the award of the Degree of Doctor of Philosophy on 31.07.2002 
List of Tables

Acknowledgements

Abstract

\section{Chapter 1}

\section{THE STUDYING POLITICS OF SOCIAL WELFARE}

Introduction

1. Defining Social Welfare

2. Different Theoretical Approaches to Social Welfare

2.1. Structural Functionalism and Social Welfare

2.2. Marxist Approaches to Social Welfare

2.2.1. Early Marxists and Social Policy

2.2.2. Neo-Marxist Theories and Social Policies

2.3. Democracy and Social Welfare

2.4. Advanced Capitalism and the Welfare State

2.5. Social Democracy and the Welfare State

3. Politics of Social Welfare in Sri Lanka

3.1. Studies on the Welfare State in Sri Lanka

3.2. Determinants of Social Welfare Policy-Making Framework in Sri Lanka 25

3.2.1. Electoral Dimension and Social Welfare Policies 28

3.2.2. Economic Performance and The Role of the Donor Agencies $\quad 30$

$\begin{array}{ll}\text { 3.2.3. Ideology and Social Welfare Policy } & 30\end{array}$

3.3. The Hypotheses and the Analytical Framework 41

3.3.1. The Working Hypotheses and the Analytical Model of the Study 42

$\begin{array}{ll}\text { 3.4. The Organization of the Thesis } & 42\end{array}$

References 


\section{Chapter 2}

\section{THE ELECTORATE AND SOCIAL WELFARE POLICIES}

Introduction

1. Social Welfare Issues and the Youth Population

1.1. Policy Responses to Unemployment

2. The Reforms in Secondary and Higher Education

3. Peasants and Electoral Issues

3.1. Policy Responses Towards the Peasants

4. Masses and Electoral Issues

4.1. The Policy Responses Towards the Ordinary Voters 74

$\begin{array}{ll}\text { 5. The Impact of Social Welfare Packages on the Electoral Outcomes } & 84 \\ \text { 5.1. Undermining the Importance of Social Welfare Issues } & 93\end{array}$

Conclusion

References

\section{Chapter 3}

\section{ECONOMIC PERFORMANCE, THE ROLE OF THE INTERNATIONAL
DONORS AND SOCIAL WELFARE IN SRI LANKA}

Introduction

1. The Emergence of the Dependent Economy

1.1. The Economic capability and Social Welfare

1.2. The Emergence of Economic Difficulties

1.3. Economic Crisis and Social Welfare

1.4. External Factors and Social Welfare

2. The Role of the IMF and the World Bank

2.1. The IMF, World Bank and the UNP Regimes 1948-1977

2.2. The IMF and the Neo-functionalist Model 1965-1970

2.3. The Role of the Donor Agencies Under the SLFP Regimes

2.3.1. The IMF-World Bank and the SLFP Regime 1956-1965

2.3.2. The IMF-World Bank and the UF Government 
3. Liberalized Economic Policies, International donors and Social Welfare
Progarames

3.1. Liberalized Policies, External Constraints, Support and Social Welfare 135

Conclusion

References

\section{Chapter 4}

\section{IDEOLOGY AND SOCIAL WELFARE POLICIES}

Introduction

1. The Emergence of the Keynesian Welfare State Ideology As the Economic
Ideology of the State

1.1. The Acceptance of the Keynesian Welfare State Ideology in 156

1.2. The Role of the State as an Entrepreneur

$\begin{array}{ll}\text { 1.3. A Period of Disengagement } & 169\end{array}$

1.4. Intensification of Public Enterprises 173

2. Party Ideologies and Social Welfare

2.1. Ideology and Land Reform 184

2.2. Tenurial and Land Reforms 185

2.3. The Paddy Lands Act of $1953 \quad 185$

$\begin{array}{ll}\text { 2.4. The Ideology of the } 1953 \text { Act } & 187\end{array}$

2.5. The Paddy Lands Act of $1958 \quad 188$

2.6. The Perception of the Paddy Lands Bill 190

2.7. Ideological Implications on the Implementation of the Paddy 192

2.8. The Land Ceiling Legislation in Sri Lanka

2.9. The Distribution and use of the Acquired Land 198

202

3. The Impact of The Keynesian Welfare State Ideology on The Welfare State 204
3.1. Changes in Income Distribution

$\begin{array}{ll}\text { 3.2. Sectoral Changes in Inequality } & 208\end{array}$

4. The Emergence of A New State Ideology 211

$\begin{array}{ll}\text { 4.1. Transmission Through A Think Tank } & 213\end{array}$

$\begin{array}{ll}\text { 4.2. The Emergence of a Market-Oriented Ideology in Sri Lanka } & 217\end{array}$

$\begin{array}{ll}\text { 4.3. The Major Components of the Market-oriented Ideology and Social Welfare } & 218\end{array}$

4.3.1. Slimming the State
4.3.2.

4.3.2. The Privatisation of State-owned Enterprises (SOES) 220 
5. The Impact of Market-Oriented Policies on Social Welfare

Conclusion

References

Chapter 5

$\underline{\text { Conclusion }}$

BIBLIOGRAPHY 


\section{LIST OF TABLES}

Page

1:1 Socio-Economic Indicators in Selected Asian Countries 26

1:2 Electoral Swings in Sri Lanka 32

3:1 Total Expenditure on Welfare Services 1949-52 (Rs. Million) 109

3:2 Balance of Trade in Sri Lanka 1948-50 (Rs. Million) 110

3:3 Central Bank Trade Indices $(1967=100) \quad 113$

3:4 Total Expenditure on Welfare Services 1956-74 (Rs. Million) 114

3:5 Sri Lanka's Export and Imports 1960-70 (Rs. Million) 115

3:6 Gross External Outstanding 1965-70 (Rs. Million) 118

$\begin{array}{lll}3: 7 & \text { Debt Service Payments 1965-70 (Rs. Million) } & 119\end{array}$

3:8 International Support for the Liberalization Regime, Saving and Investment (As a Percentage of GDP, Current Market Prices) 144

4:1 Real GDP Per Capita and Real Public Expenditure Per Capita On Social Services, Sri Lanka, 1950-51/1977 (Rs. At 1959 Prices) 163

4:2 Social Expenditure as a Percentage of GNP 165

4:3 Total Expenditure on Welfare Services (Rs. Million) 167

4:4 The Origins of Public Enterprises and Their Growth Up to $1974 \quad 184$

4:5 Paddy Lands by Type of Tenure, $1946 \quad 186$

4:6 Percentage of Total Income Received by Each Tenth of Income Receivers and Spending Units (All Island) 209

$\begin{array}{lll}4: 7 & \text { Concentration Ratios } & 210\end{array}$

4:8 Percentage of Total Income Received by Each Tenth of Income Received 212

4:9 Redundancy Rates in Selected State-owned Enterprises 227

4:10 Food Subsidies and Household Transfers, 1977-82 (Rs. Million) 230

$\begin{array}{lll}4: 11 & \text { Colombo Consumers' Price Index } 1977 & 231\end{array}$

4:12 Minimum Wage Rate Indices, 1978-84 (December 1978=100) 232

4:13 Relative Income Distribution Data, 1978/79, 1981/82, 1986/97, 1996/97 (Percentage of Income Received by Decile of Income Receivers and Spending Units)

4:14 Gini Coefficient 234

4:15 Real GDP Per Capita and Real Per Capita Expenditure on Education 236 And Health, 1978-2000 (Rs. At 1959 Prices) 239 


\section{ACKNOWLEDGEMENTS}

The first draft of this study was completed under the supervision of Professor Frank W. Bealey, Professor of Political Science, at the University of Aberdeen in the UK. However, the final draft of the study was completed on the basis of the comments provided by Professor Y.R. Amarasinghe, Professor of Political Science, at the University of Peradeniya and Dr. Navaratne Bandara, Senior Lecturer in Political Science, at the University of Peradeniya. I am deeply indebted to Professor Y.R.Amarasinghe and Dr. Navaratna Bandara for their critical comments for the completion of the final draft.

The first draft of the study was completed on the basis of a Commonwealth Academic Staff Scholarship granted by the Commonwealth Scholarship Commission in the United Kingdom and jointly administered by the British Council and the Association of Commonwealth Universities. Therefore, I would like to express sincere gratitude to them.

Several libraries provided indispensable help. These included the University of Aberdeen, the School of Oriental and African Studies, the University of Sri Jayewardenepura, the National Archives Department in Sri Lanka and the Colombo Museum.

Last, but not least, I would like to thank to my wife, Manel, for her encouragement given to me in this effort. 


\title{
THE IMPACT OF POLITICS ON SOCIAL WELFARE POLICIES A STUDY OF POST-INDEPENDENCE SRI LANKA 1948-2000
}

\author{
P. Athukoralage
}

\begin{abstract}
The study attempts to examine the relationship between social welfare and politics in post-independence Sri Lanka. The objective is to develop an analytical framework under which we could identify the welfare policy-making process with structural dimension attached to it. This has been attempted by examining different factors that influenced the social welfare policy-making process in Sri Lanka.
\end{abstract}

The findings of this identified the electorate, the performance of the economy, the role of the international donors, the ideology of the ruling parties and the state economic ideology as the determinants of the social welfare policy-making process in Sri Lanka. The ruling regime's willingness to introduce more social welfare policies, its capability of allocating more funds for social welfare and finally the state's commitment to maintain a social welfare policy sector within the sphere of public policy were influenced by the above determinants.

There is a direct relationship between the electorate and the social welfare issues in a democratic country. The behaviour of the voter is determined by various factors, but the study follows the positive public choice approach, which assumes the behaviour of the voter is decided on the basis of social welfare policy packages. The study examines to what extent social welfare issues have influenced the final outcomes of general elections held in post-independence Sri Lanka. 
The performance of the economy is probably the conditional factor which would determine the real shape of the intended social welfare policy of the government. The policy makers in Sri Lanka could not ignore the capability of the economy when deciding the policy priorities, i.e. "who gets, what, when and how" in response to the electoral and party ideological considerations. The study examines how the economic capabilities influence the formulation of social welfare policies in the country.

The role of the international donors such as the IMF and the World Bank is also important, as these institutions force the developing world to move from the Keynesian welfare approach to the current market-led welfare approach. These institutions have now acquired a very influential role in deciding the economic ideology of the Sri Lankan state due to its high reliance on foreign borrowings and the global economic strategies introduced by these institutions. The study examines the extent to which some of the recommendations imposed by the IMF and the World Bank have affected the social welfare programmes in the country and how they have finally influenced the economic ideology of the state.

The ideologies of the ruling parties always affect the welfare policy commitment of the government. The party ideological commitment either towards the market economy or the command economy will determine the regime's interest in maintaining social welfare programmes. In the light of this argument the ideologies of the two major parties, the UNP and the SLFP, which have ruled the country alternately during the post-independence period with some coalition partners, have also been examined as a determinant of social welfare policies in Sri Lanka.

The economic ideology of the state is the most important determinant in the formulation of social welfare policies. The compulsion or commitment of the 
state for introducing social welfare policies will be determined by the economic ideology of the state. Thus it can be considered as the guiding principle in the formulation of social welfare policies. The study examines how the two broad state ideologies, namely, the Keynesian welfare state ideology and the NeoLiberal ideology, influenced the formulation of social welfare policies in Sri Lanka. 


\section{Chapter 1}

\section{STUDING POLITICS OF SOCIAL WELFARE}

\section{INTRODUCTION}

There is a strong relationship between social welfare and politics in Sri Lanka. The process of establishing the welfare state in the country began before independence. It persisted during the post-independence period.

The present study attempts to examine the major determinants of the welfare policymaking process in Sri Lanka. The objective is to develop an analytical framework under which we could identify the welfare policy-making process. This has been attempted by examining different factors that influenced the social welfare policymaking process in post-independence Sri Lanka.

This chapter will discuss the conceptual and theoretical background relating to the

study. It will also explain the research problem, and the broad objectives of my attempt.

\section{DEFINING SOCIAL WELFARE}

J.A.Hobson in 1929 wrote that 'welfare' may mean anything from the most elevated conception of human character and destiny to the baths, refectories and recreation 
grounds that figure so prominently in what is known as 'welfare work'(Hobson, 1929:10).

Welfare in the broadest sense is enjoyed largely through the consumption of goods and services that money can buy; and money is wealth. It is also true that the welfare or social services have been mainly concerned, during the greater part of their history, with supply of goods and services to those poor, who are unable to buy them; welfare in this sense was a substitute for money, or wealth. Yet wealth and welfare even in the form of things that money can buy, are not identical. Economists discovered this when they began to examine the concept of marginal utility. For as one writer puts it, "under the impact of the marginal revolution...economic thought started moving away from the classical materialistic level to the modern subjective level of analysis" (Marshall, 1981:54)

What had to be measured, in other words, was not an absolute quantity of physical goods or services, but the satisfaction gained from them by the consumer, which varies from case to case, according to circumstances. Whereas the possession of goods or of money is wealth, the satisfaction of want is welfare.

In terms of the above definition welfare consists in the satisfaction of wants "belonging to the 'material' aspect of life, capable of being brought into relation with the measuring rod of money" (Marshall, 1981:54). According to Marshall economic welfare is not the only kind of welfare. He questions whether it is possible to assess the satisfaction that a social worker gives to an aged widow, a handicapped child, or 
a destitute family purely in terms of money (Marshall, 1981:54). The commodities consumed in such cases include intangible things like sympathy, courage, hope and even perhaps happiness and they cannot be measured in money. "Welfare is entangled with happiness, just as it is with wealth, but is not identical with it"(Marshall, 1981:55). It must be distinguished from both of them, but can be wholly detached from neither.

The idea of social welfare has several major components, each of which has various dimensions. As suggested above, it may be taken to mean a certain kind of good or benefit, or a collection of goods, or even more broadly an unspecified set of good things. Finally, both goods and services which can be valued in terms of money in the market, and individual satisfaction which cannot be thus valued may be included in the concept of social welfare.

The process of including social welfare policies into the area of the public policymaking began during the nineteenth and twentieth centuries. The State intervention took place from the early $19^{\text {th }}$ century in the areas of education, health and industries. Between the 1880 s and the 1920 s social insurance and pension programmes were launched in Europe, in the USA and Australasia (Flora and Alber 1981. Malloy 1979, Rimlinger 1971). After the introduction of these programmes in the above countries those programmes spread to other countries in the world. In the wake of World War Two, most of the leading capitalist countries became selfproclaimed 'welfare states' (Flora and Heidenheimer 1981). By the mid 1970s, public expenditures for social welfare purposes had increased to an average of 
$20.7 \%$ of GDP in 13 European nations and even in the USA such expenditures had increased from $10.3 \%$ to $15.7 \%$ of GDP between the early 1960 s and the mid-1970s (Castles, 1982:51).

Thus, major social welfare policy areas such as education, health, transport and other social insurance programmes of the government entered into public policy all over the world. Therefore, the responsibility of maintaining those policies on behalf of the people fell into the hands of the government. In the 1960s and the 1970s, governments all over the world began to intervene in their economies in order to maintain the above social welfare policies.

\section{THE DIFFERENT THEORETICAL APPROACHES TO SOCIAL}

\section{WELFARE}

Before discussing the case of Sri Lanka in this regard, it is necessary to examine different approaches of social welfare policies. This section attempts to survey those different approaches under structural functionalism, Marxism and Neo-Marxism, democracy, advanced capitalism and social democracy.

\section{2:1 Structural Functionalism and Social Policy}

Structural functionalists who studied the emergence of social policies have argued that industrialism was the crucial factor in the emergence of social welfare policies. According to structural functionalism, "Economic growth is the ultimate cause of the evolution of the welfare state" (Wilensky, 1975:24, Wilensky and Lebeaux, 1958:230). Further, the nations began to move from a traditional-agrarian society to a 